\title{
ALTERNATIVE OPTICAL METHODS FOR QUALITATIVE DETECTION OF VITAMIN B6 AND B12 OF BANANA
}

\author{
[Metode Optik Alternatif untuk Deteksi Vitamin B6 dan B12 \\ secara Kualitatif pada Pisang]
}

\author{
Isnaeni ${ }^{*}$, Baladika Sukma Zufara, and Ismira Wahyu Lestari Lewa \\ Research Center for Physics, Indonesian Institute of Science, Puspiptek, South Tangerang, Banten
}

Received February $3^{\text {rd }} 2020$ / Accepted December $10^{\text {th }} 2020$

\begin{abstract}
Bananas are known to contain fiber and vitamins essential for human body. Thus, the ability to detect these of vitamin in bananas is crucial. Information in the vitamin content of can affect procedures for harverst and post-harvest process. Methods to determine the nutrition content of foods are usually carried out using High Performance Liquid Chromatography (HPLC). However, this method requires complex sample preparation and chemical reaction processes. Due to this weakness, alternative techniques are needed to detect vitamin in simple ways. In this study, a simple, easy and fast methods to determine the vitamin content of banana was developed. Using reflectance and photoluminence spectroscopy, the vitamin of bananas from five different species were able to be identified. From the reflectance spectra results, two peaks were observed, the first peak at a wavelength of $325 \mathrm{~nm}$ is the absorption peak of vitamin B6 and the second peak at $450 \mathrm{~nm}$ is the absorption peak of vitamin B12. From the photoluminence spectra using excitation wavelength at $325 \mathrm{~nm}$, an emission peak was found at wavelength $450 \mathrm{~nm}$ which is the peak emission from vitamin B6. These results proved that by using the methods proposed, the detection of vitamins in bananas can be done in an easy and simple ways.
\end{abstract}

Keywords: absorbance, banana, luminescence, reflectance, vitamin

\begin{abstract}
ABSTRAK
Pisang diketahui mengandung serat dan vitamin yang baik untuk tubuh manusia. Kondisi ini membuat deteksi vitamin dalam pisang menjadi penting untuk dilakukan. Informasi tentang kandungan vitamin pisang dapat memengaruhi cara panen dan proses pascapanen. Metode untuk menentukan nutrisi pada buah dan bahan makanan biasanya dilakukan dengan menggunakan High Performance Liquid Cromatography (HPLC). Kekurangan dari metode ini membutuhkan preparasi sampel yang kompleks dan melibatkan reaksi kimia yang kompleks. Kekurangan ini, teknik alternatif diperlukan untuk mendeteksi vitamin secara sederhana. Pada penelitian ini, metode sederhana, mudah, dan cepat untuk menentukan kandungan vitamin pisang untuk dilakukan. Kandungan vitamin dari lima spesies yang berbeda dapat diidentifikasi menggunakan spektroskopi reflektansi dan fotoluminensi. Hasil spektrum reflektansi, terdapat dua puncak yaitu puncak pertama pada panjang gelombang $325 \mathrm{~nm}$ yang merupakan puncak serapan vitamin B6 dan puncak kedua pada panjang gelombang $450 \mathrm{~nm}$ yang merupakan puncak serapan vitamin B12. Spektrum fotoluminensi menggunakan panjang gelombang $325 \mathrm{~nm}$, puncak emisi ditemukan pada panjang gelombang $450 \mathrm{~nm}$ yang merupakan puncak emisi dari vitamin B6. Hasil ini membuktikan bahwa dengan menggunakan metode yang diusulkan deteksi vitamin dalam pisang dapat dilakukan dengan cara yang mudah dan sederhana.
\end{abstract}

Kata kunci: absorbansi, luminensi, pisang, reflektansi, vitamin

\section{INTRODUCTION}

Indonesia is a tropical country that lies exactly on equator line. This location makes Indonesia is a great place to grow tropical fruits, such as guava,

${ }^{*}$ Corresponding Author:

E-mail: isnaeni@lipi.go.id papaya, star fruit, pineapples and bananas (Kumoro et al., 2020; Bhat et al., 2016). In Indonesia, there are a lot of species of bananas. Each of them has unique taste and shape. Bananas are well known as excellent nutrition source for human body, since bananas contain potassium, vitamin C, B6, fiber, amino acids, and tryptophan (Sampson et al., 2014). 
Although bananas have good nutrition, nutrition level of each species of bananas might different.

Increasing the economic condition and people's living standards, fruit consumption increases. Banana is one of the most commonly eaten fruit in the world (Sampson et al., 2014). According to this condition, it is important to determine the nutrients contained in bananas. Analysis of nutrition in Bananas is very important for consumers and producers. Nowadays, consumers pay attention to the nutritional factors contained in the food they eat (Spínola et al., 2014). For producers, knowing the nutritional content in fruit is important for controlling the fruit processing post harvested. Not only external quality, but internal with determining the nutrition inside the fruit is also important to observed.

During the recent years, checking the quality of fruit is done in a traditional ways like observing the skin color changes using direct observation. However this methods is subjective and time consuming. Many researchers propose several methods used to determine nutrition of fruit and food. One of the methods is chromatography. Nowadays, in order to verify nutrition content of food, engineers use high performance liquid chromatography (HPLC) (Klimczak et al., 2015). This measurement is quite complicated. Since, it uses a specific column and reference sample for every measurement. However, the vitamin content in the fruit can be quickly lost under certain condition such as heating process (Klimczak et al., 2015). In addition, this method is only can be done in laboratory scale. Hence, it is difficult to detect the nutrition in fruit on a large scale.

To overcome the lack of mass quality detection, detection methods that can provide the internal content of fruits and non-destructive methods are needed (Zerbini et al., 2015). There are several analytical methods such as acoustic technique, spectroscopic technique, machine vision, and electronic noses. The internal properties of the fruit cannot be detected using machine vision system techniques (Lu et al., 2011). Spectroscopic method is a promising optical technique that can be used to measure directly. This method is simple, does not require pre-treatment of samples and chemical reactions. By using this method, detection process of nutrition in fruit can be done without damaging the surface of the fruit (Wang et al., 2015).

The optical method studies the interaction between light and matter. From this interaction, the characteristics and properties of material can be studied. Study of the interaction between light and biological tissues has become an attraction in agriculture and biomedical fields because this phenomenon can provide indepth information about the chemical and physical properties of tissues through absorbance and scattering processes ( $\mathrm{Hu}$ et al., 2015). Several studies have succeeded in observing quality of fruit using optical methods (Adebayo et al., 2017; Hashim et al., 2012). In addition, optical methods such as backscattering and Vis/NIR spectroscopy have also been used to observe the mechanical properties, firmness, $\mathrm{pH}$, and the structure of the fruit (Cen et al., 2013; Huang et al., 2018; Rowe et al., 2014; Zhu et al., 2015). In this work, the simple and rapid methods for detecting vitamin in bananas were proposed. The purpose this study is to qualitatively measure vitamin content in five species of bananas using reflectance spectroscopy and photoluminescence spectroscopy. By using these techniques, we can get the information related to the fruit quality with simple, fast and no need a complex extraction process. Thus, these methods are possible for large scale detection in industry.

\section{MATERIALS AND METHODS}

\section{Materials}

All the analysis and observations do not require chemical reactions. Therefore, banana is the only material used in this study. All bananas were obtained from local Serpong traditional market, South Tangerang, Banten, Indonesia. Information obtained from seller is that the origin of bananas was Bogor, West Java, Indonesia. Banana that used in this experiment was five species of local bananas in Indonesia. They are banana kepok (Figure 1A), banana sereh (Figure 1B), banana susu (Figure 1C), banana uli (Figure 1D) and banana nangka (Figure $1 \mathrm{E})$. Bananas used in this study are bananas with perfect maturity which is around 110-150 days after flowering.

\section{Methods}

The procedure for preparing samples is done by peeling bananas obtained from traditional markets. Then, banana sliced with diameter around $3 \mathrm{~cm}$. Furthermore, the sliced banana is placed on a glass preparation to be observed. Observations were made by repeated observations at 3 different points on the banana flesh.

Equipments used in this work are knife, object glass. For reflectance system, the equipments are the light source (deuterium and halogen lamp) from Ocean Optics USA Florida, fiber optic, and spectrometer (MAYA Pro2000, Ocean Optics). For photoluminescence system, the equipments are 325 $\mathrm{nm}$ laser source from Ocean Optics, fiber optic, and spectrometer (MAYA Pro2000, Ocean Optics from Florida USA). Optical fiber was used to capture the signal produced by the interaction between light and banana in the form of emission and reflectance spectra. The experiments are carried out without going through the extraction process, involving chemicals, or complex instruments. The experiments 
only use the tools and materials mentioned in this manuscript.

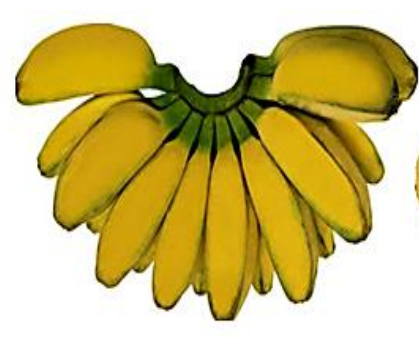

A

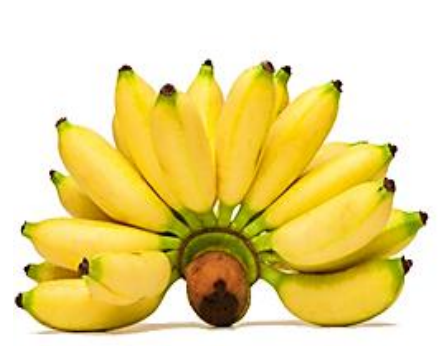

C

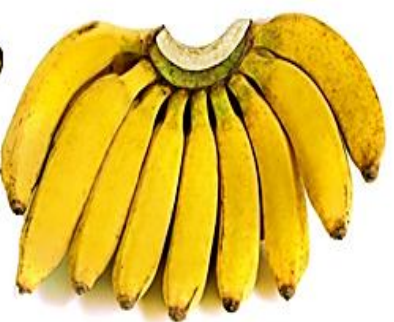

B

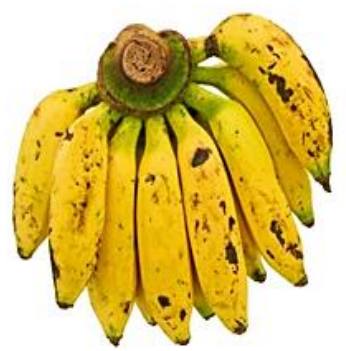

D

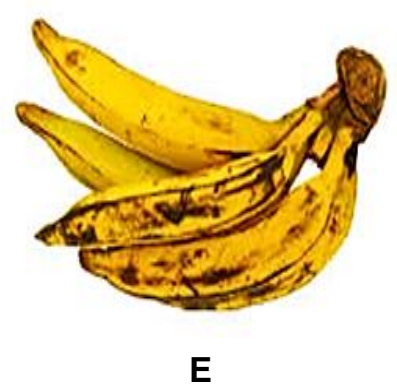

Note: $\mathrm{A}=$ Banana kepok; $\mathrm{B}=$ Banana sereh; $\mathrm{C}=$ Banana susu; $\mathrm{D}=$ Banana uli; $\mathrm{E}=$ Banana nangka

Figure 1. Five different bananas used in this research

The observation method is carried out by using two optical measurement systems i.e. reflectance spectroscopy and photoluminescence spectroscopy. The method used in this study is a method that has been modified and simplified from several methods that have been carried out by several previous research (Valvidivieso et al., 2014; Jaiswal et al., 2012). The system used in this study is very simple and does not require special pre-treatment actions.

Reflectance spectroscopy investigation utilized deuterium and halogen lamp as light source. The light was coupled into the fiber optic, directed to the banana flash. Furthermore, the reflectance signal from the banana is captured by the same optical fiber and recorded by a spectrometer. This spectrum is then transmitted to the computer for data analysis. Observation data is then compared with some previous studies to find out what nutritional information that obtained in experiment.

For photoluminescence, laser ultraviolet at wavelength $325 \mathrm{~nm}$ was used to excited banana sample. The emission from banana was then collected by spectrometer probe. For both photoluminescence and reflectance spectroscopy, only used wavelength from 300 to $900 \mathrm{~nm}$ to analyze the vitamin content in Bananas. Each bananas were measured 5 times to get measurement consistency. The same spectra are obtained for every repeated measurement.

Furthermore, absorbance spectrum of bananas is observed. Therefore Kubelka-Munk (KM) formula to convert reflectance spectra into absorbance spectra as follow was used:

$\frac{K}{S}=\frac{(1-R)^{2}}{2 R}$

$\mathrm{K} / \mathrm{S}$ is an absorbance over scattering and $\mathrm{R}$ is reflectance (Lana et al., 2006).

\section{RESULTS AND DISCUSSION}

\section{Optical characteristics of bananas}

Optical characteristic studies the interaction between light and material to determine the properties of the material to be observed. When light hits a sample, there are three possible phenomenon that occur i.e. reflectance, transmittance and absorbance. From this optical phenomenon, the information about the properties of a material can be obtained (Wang et al., 2015).

Material based on optical properties can be divided into three types i.e. transparent, semitransparent and turbid. Biological objects such as banana tissue are classified into semi-transparent or turbid material (Mireei et al., 2010). Optical characterization of biological tissue has several challenges, namely complex since the events of reflection, absorption, and scattering occur at the same time (Qin et al., 2007). Light hits biological tissue, only about $4-5 \%$ of light can be reflected (Mireei et al., 2010). The rest passes through the surface and interacts with the internal components of this biological tissue. This event is the basis for characterizing optical properties in bananas.

Observations using optical methods are simple and rapid. Since, it does not require complicated sample preparation like other methods such as HPLC. Research conducted by Koyuncu et al. (2010) uses the HPLC method to determine the vitamin $C$ content of strawberries, the testing procedure requires extraction of strawberries with certain $\mathrm{PH}$ rules (Koyuncu et al., 2010). Furthermore, Gundogdu et al. (2011) identified the vitamin content 
of berries which required the samples to be extracted and supplemented with chemicals such as $\mathrm{H}_{2} \mathrm{SO}_{4}$ which were harmful to the environment. In addition, using HPLC requires a standard solution so that it involves more chemical materials (Gundogdu et al., 2011). By replacing these methods with optical spectroscopy method, observations can be simpler, faster, and safer for the environment.

\section{Reflectance spectra of bananas}

Reflectance spectroscopy is the investigation of the spectral composition of surface-reflected radiation with respect to its angularly dependent intensity and the composition of the incident primary radiation. The reflectance spectroscopy measurement was done very quickly.

There are similar reflectance spectra for all bananas. The reflectance dips and peaks are almost identical (Figure 2). However, the reflectance intensities are different. Reflectance spectroscopy was done. Since, any sample preparations in this measurement do not want to be skipped. This procedure makes the measurement applicable in the field. Therefore edible banana part was chosen directly for measurement.

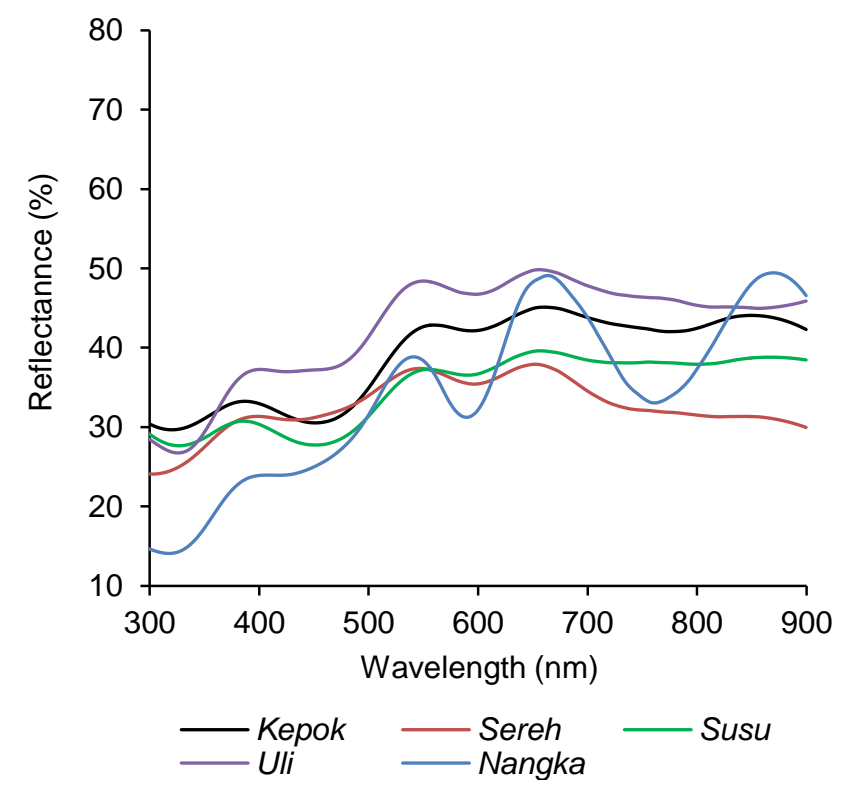

Figure 2. Reflectance spectra of five species of bananas

Figure 2 show that there is same peak of reflectance but different in intensities. The spectrum, there are four absorption regions at wavelengths of 300 to $320 \mathrm{~nm}$. The peak at this wavelength is related to the uptake of Pyridoxine or better known as vitamin B6 (Bilski et al., 2000). The second peak is at a wavelength of 450 which is the absorption of vitamin B12 (Wang et al., 2015). While the third and fourth peaks are predicted to be absorption from chlorophyll. To confirm this result, the reflectance spectrum was converted into absorbance. Observation of the structure of fruit and food using reflectance spectroscopy has been carried out by several previous studies (Davey et al., 2009; Subedi et al., 2011).

\section{Absorbance spectra of bananas}

The KM methods is applicable to homogeneous tissues, and also can provide inhomogeneous and layered tissues with analytical expression of both transmittance or reflectance (Roy et al., 2012). The $\mathrm{KM}$ model was known as the dual flux radiation transmission model. It has been used to study the optical properties of inhomogeneous media. The KM theory describes propagation of uniform, diffuse irradiance through one dimensional isotropic slab with no reflection at the boundaries. However, this model is empirical and has poor accuracy as a viable method for measurement of tissue optical properties. Therefore, it still needs to be studied and developed.

Absorbance spectra can be seen in Figure 3. Reflectance spectra of five banana species were converted into absorbance spectra. Basically, reflectance spectra and absorbance spectra consist of similar information; however, absorbance spectra are more familiar and easier to understand than reflectance spectra. The absorbance (K/S curve) spectra of bananas are shown in Figure 3.

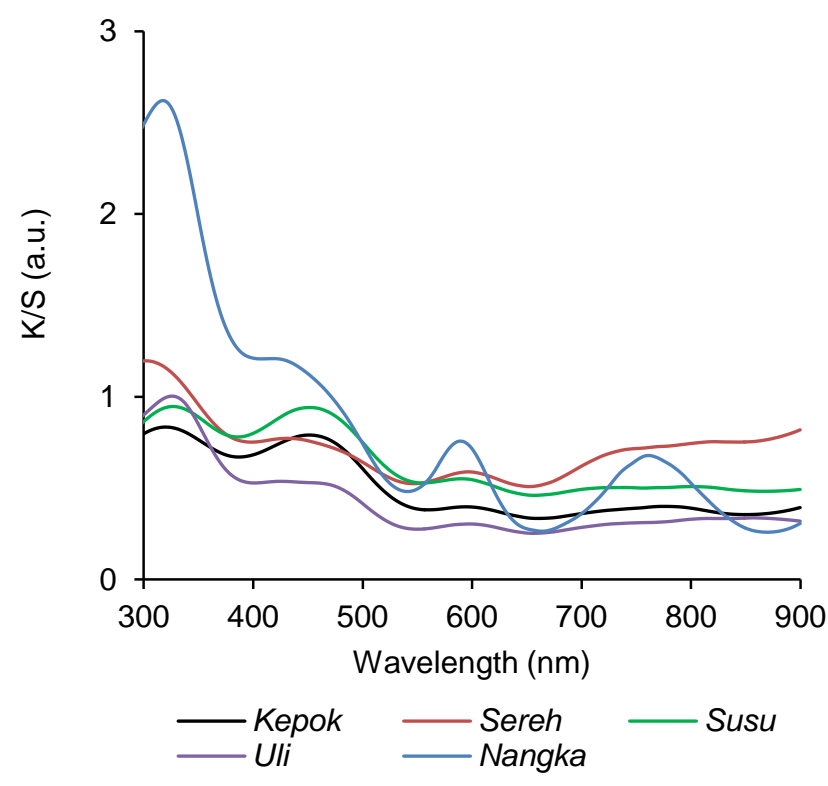

Figure 3. Absorbance spectra of five species of bananas

Similar to reflectance spectra, absorbance spectra of bananas are almost identical in term of 
absorbance peak wavelength. However, the absorbance peak intensities are significantly different. In order to clarify this finding, multi-peak fitting (deconvolution) of each absorbance spectrum was performed. Gaussian fitting curves were used in this process, since most of organic spectra are Gaussian (Massicotte et al., 2016). Gaussian fitting is an approach for removing frequency noise from a spectrum. The purpose of using this approach is to obtain an optimal value through the fitting or averaging of several points.

Figure $4 \mathrm{~A}$ show the fitting results of absorbance spectrum of banana kepok. The black curve is the measured absorbance spectrum. The red line curve is our fitting result from multi-peak fitting. The fitting result is matched very well to measured absorbance. The fitting result indicates that there are at least 4 Gaussian deconvolution curves as shown in Figure $5 B$. These four curves build red fitting curve in Figure 4A. From Figure 4B, each peak wavelength can be investigated and normalized. Furthermore, the same fitting procedure was conducted for all absorbance spectra of remaining bananas. The full list of fitting parameters i.e., peak wavelength and peak intensity of all Gaussians fitting curves for all bananas, can be seen in Table 1 .

From Table 1, can be seen that curve 1 has dominant peak at every absorbance spectra. Curve 1 has peak wavelength at around 301 until $325 \mathrm{~nm}$. This absorbance peak wavelength is predicted as absorbance of pyridoxine, which is known as (vitamin B6). Second most dominant curve is curve 2. banana sereh and banana uli has low peak intensity of curve 2. Other bananas show strong curve 2, which has absorbance at 432 until $453 \mathrm{~nm}$. This peak is predicted as absorbance of vitamin B12. Furthermore, curve 3 and 4 are related to chlorophyll absorbance (Chen et al., 2010; Hashim et al., 2012).

\section{Photoluminence spectra of bananas}

In addition to reflectance spectroscopy, photoluminescence spectroscopy was used to observe the optical properties of bananas. Basically, bananas were excited using ultraviolet light to generate luminescent that comes out from bananas. Figure 5 shows luminescent spectra of five banana species upon laser $325 \mathrm{~nm}$ wavelength excitation.
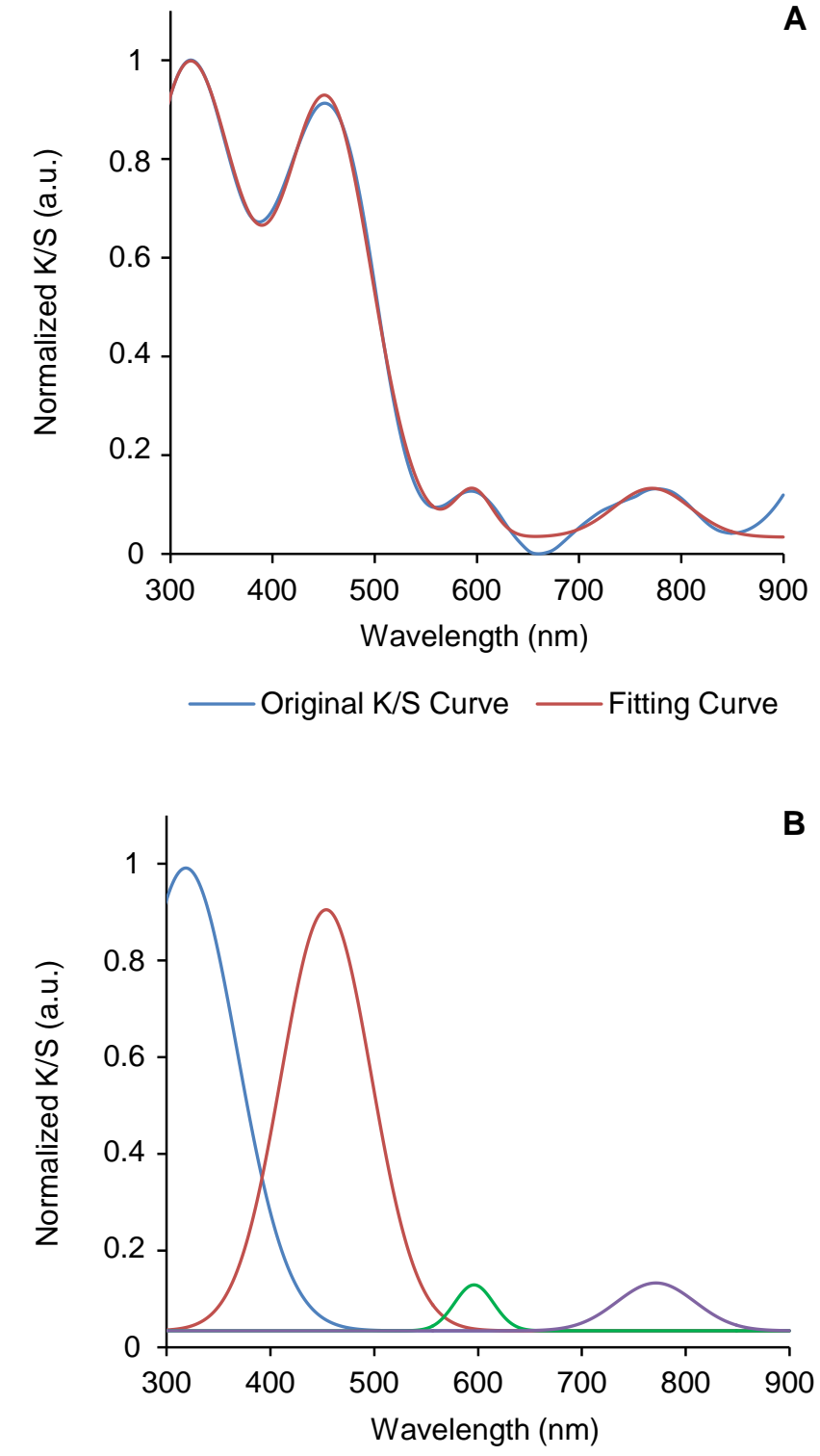

Figure 4. Fitting curve of K/S spectra $(A)$ and deconvolution curves (B) of $\mathrm{K} / \mathrm{S}$ spectra of banana kepok

Table 1. Absorbance peak wavelength (A) and normalized absorbance peak intensity (B) of four fitting curves of five bananas

\begin{tabular}{lcccccccc}
\hline \multirow{2}{*}{ Sample } & \multicolumn{3}{c}{ Peak Wavelength $(\mathrm{nm})$ of Curve $(\mathrm{A})$} & \multicolumn{4}{c}{ Peak Intensity (a.u.) of Curve (B) } \\
\cline { 2 - 9 } & 1 & 2 & 3 & 4 & 1 & 2 & 3 & 4 \\
\hline Banana kepok & 318 & 453 & 596 & 768 & 1.00 & 0.91 & 0.13 & 0.13 \\
Banana sereh & 301 & 434 & 597 & 741 & 1.00 & 0.38 & 0.12 & 0.29 \\
Banana susu & 329 & 448 & 591 & 729 & 1.00 & 0.98 & 0.18 & 0.09 \\
Banana uli & 325 & 452 & 597 & 739 & 1.00 & 0.37 & 0.07 & 0.07 \\
Banana nangka & 315 & 432 & 591 & 763 & 1.00 & 0.39 & 0.21 & 0.18 \\
\hline
\end{tabular}



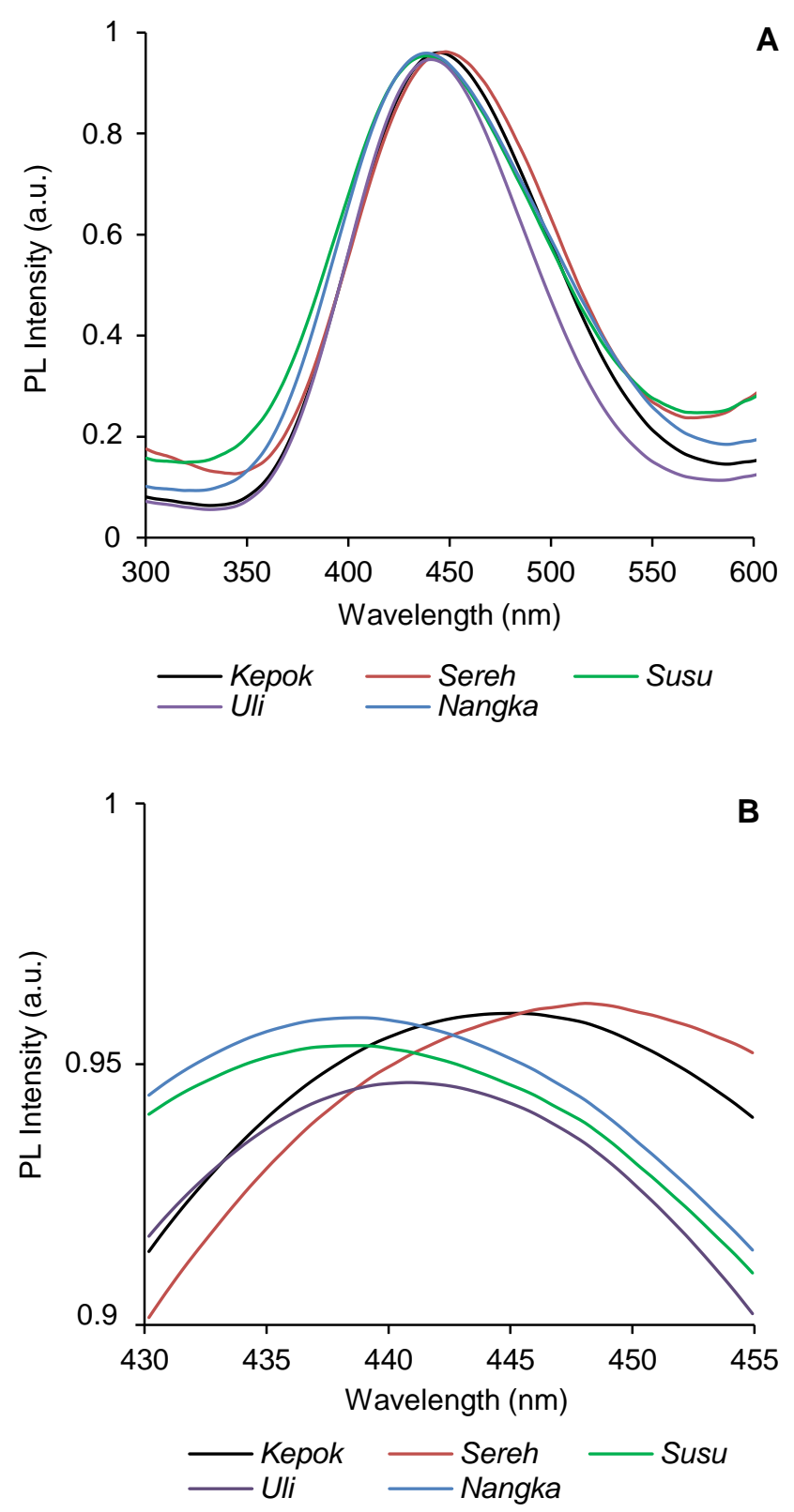

Figure 1. Photoluminescence spectra of five bananas excited by $325 \mathrm{~nm}$ laser (A) and magnification of peak photoluminescence spectra for five bananas $(B)$

\section{CONCLUSION}

In this study, alternative methods for detecting nutrition of five local banana species using reflectance spectroscopy and photoluminescence was conducted successfully. The absorbance spectra, which were obtained from reflectance spectra, consist of four Gaussian fitting curves. The first and second curves indicate absorbance of vitamin B6 and B12, respectively. Furthermore, the wavelength
A of luminescence maximum peak slightly varies from 437 until $448 \mathrm{~nm}$. By using these techniques, we can get the information related to the fruit quality with simple, fast and no need a complex extraction process. Thus, these methods are possible for large scale detection in industry.

\section{ACKNOWLEDGEMENT}

This work is supported by Insinas Program 2019 from Ministry Research and Higher Education Republic of Indonesia and DIPA Project from Research Center for Physics Indonesian Institute of Sciences Number: 8442/ IPT.1/A/2019.

\section{REFERENCES}

Adebayo SE, Hashim N, Abdan K, Hanafi M, Mollazade K. 2016. Prediction of quality attributes and ripeness classification of bananas using optical properties. Sci Hortic-Amsterdam 212: 171-182. DOI: 10.1016/j.scienta.2016.09. 045.

Bhat R, Paliyath G. 2016. Fruits of Tropical Climates: Biodiversity and Dietary Importance. In: Caballero B, Finglas PM, Toldrá F, eds. Encyclopedia of Food and Health. 138-143. Academic Press, Oxford. DOI: 10.1016/B978-012-384947-2.00337-8.

Bilski P, Li MY, Ehrenshaft M, Daub ME, Chignell CF. 2000. Vitamin B6 (pyridoxine) and its derivatives are efficient singlet oxygen quenchers and potential fungal antioxidants. Photochem Photobiol 71: 129-134. DOI: 10.1562/0031-86 55(2000)071<0129:SIPVBP>2.0.CO;2.

Cen H, Lu R, Mendoza F, Beaudry RM. 2013. Relationship of the optical absorption and scattering properties with mechanical and structural properties of apple tissue. Postharvest Biol Tec 85: 30-38. DOI: 10.1016/j.postharvbio.2013.04. 014.

Chen M, Schliep, Willows RD, Cai Z-L, Neilan BA, Scheer H. 2010. A red-shifted chlorophyll. Science 32: 1318-1319. DOI: 10.1126/science. 1191127.

Davey MW, Saeys W, Hof E, Ramon H, Swennen, $\mathrm{RL}$, Keulemans J. 2009. Application of visible and near-infrared reflectance spectroscopy (Vis/NIRS) to determine carotenoid contents in banana (Musa spp.) fruit pulp. J Agric Food Chem 57: 1742-1751. DOI: 10.1021/jf803137d. 
Gundogdu M, Muradoglu F, Sensoy RIG, Yilmaz H. 2011. Determination of fruit chemical properties of Morus nigra L, Morus alba L, Morus rubra L by HPLC. Sci Hortic-Amsterdam 132: 37-41. DOI: 10.1016/j.scienta.2011.09.035.

Hashim N, Janius RB, Baranyai L, Rahman RA, Osman A, Zude M. 2012. Kinetic model for colour changes in bananas during the appearance of chilling injury symptomps. Food Bioprocess Tech 5: 2952-2963. DOI: 10.1007/s11947-0110646-z

Hu D, Fu X, Wang A, Ying Y. 2015. Measurement methods for optical absorption and scattering properties of fruits and vegetables. Am Soc Agric Biologic Eng 58: 1387-1401. DOI: 10.13 031/trans.58.11103.

Huang Y, Lu R, Hu D, Chen K. 2018. Quality assessment of tomato fruit by optical absorption and scattering properties. Postharvest Biol Tec 143: 78-85. DOI: 10.1016/j.postharvbio. 2018.04.016

Jaiswal P, Jha SN, Bharadwaj R. 2012. Nondestructive prediction of quality of intact banana using spectroscopy. Sci Hortic-Amsterdam 135: 14-22. DOI: 10.1016/j.scienta.2011.11.021.

Klimczak I, Gliszczyńska-Świgło A. 2015. Comparison of UPLC and HPLC methods for determination of vitamin C. Food Chem 175: 100-105. DOI: 10.1016/j.foodchem.2014.11.104.

Koyuncu MA, Tuba D. 2010. Determination of vitamin $\mathrm{C}$ and organic acid changes in strawberry by HPLC during cold storage. Notulae Botanicae Horti Agrobotanici Cluj-Napoca 38: 95-98.

Kumoro AC, Alhanif M, Wardhani DH. 2020. A critical review on tropical fruits seeds as prospective sources of nutritional and bioactive compounds for functional foods development: A case of indonesian exotic fruits. Int J Food Sci 2020: 1-15. DOI: 10.1155/2020/4051475.

Lana MM, Hogenkamp M, Koehorst RBM. 2006. Application of Kubelka-Munk analysis to study of translucency in fresh-cut tomato. Innov Food Sci Emerg Technol 7: 302-308. DOI: 10.1016/j.i fset.2006.04.001.

Lu R, Ariana DP, Cen H. 2011. Optical absorption and scattering properties of normal and defective pickling cucumbers for 700-1000 Nm. Sens Instrument Food Qual Safety 5: 51-56. DOI: 10.1007/s11694-011-9108-6.

Martínez-Valdivieso D, Font R, Blanco-Díaz MT, Moreno-Rojas JM, Gómez P, Alonso-Moraga A, Río-Celestinoa MD. 2014. Application of near- infrared reflectance spectroscopy for predictiing carotenoid content in summer squash fruit. Comput Electron Agr 108: 71-79. DOI: 10.1016/ j.compag.2014.07.003.

Massicotte P, Markager S. 2016. Using a Gaussian decomposition approach to model absorption spectra of chromophoric dissolved organic matter. Mar Chem 180: 24-32. DOI: 10.1016/j. marchem.2016.01.008.

Mireei SA, Mohtasebi SS, Massudi R, Rafiee S, Arabanian AS, Berardinelli A. 2010. Non-destructive measurement of moisture and soluble solids content of mazafati date fruit by NIR spectroscopy. Australian J Crop Sc 4: 175-79.

Müller T, Kräutler B. 2011. Chlorophyll breakdown as seen in bananas: Sign of aging and ripeninga mini-review. Gerontology 57: 521-527. DOI: 10.1159/000321877

Qin J, Lu R. 2007. Measurement of the absorption and scattering properties of turbid liquid foods using hyperspectral imaging. Appl Spectrosc 61: 388-396. DOI: 10.1366/0003702077804661 90.

Rowe PI, Künnemeyer R, McGlone A, Talele S, Martinsen P, Seelye A. 2014. Relationship between tissue firmness and optical properties of 'Royal Gala' apples from 400 to $1050 \mathrm{Nm}$." Postharvest Biol Tec 94: 89-96. DOI: 10.1016/ j.postharvbio.2014.03.007.

Roy A, Ramasubramaniam R, Gaonkar HA. 2012. Empirical relationship between Kubelka-Munk and radiative transfer coefficients for extracting optical parameters of tissues in diffusive and nondiffusive regimes. J Biomedical Optics 17: 115006. DOI: 10.1117/1.JBO.17.11.115006.

Sampson HA, Aceves S, Bock SA, James J, Jones S, Lang D, Nadeau K, Nowak-Wegrzyn A, Oppenheimer J, Perry TT, Randolph C, Sicherer SH, Simon RA, Vickery BP, Wood R. 2014. Food allergy: A Practice parameter update-2014. J Allergy Clinical Immun 134: 1016-1025. DOI: 10.1016/j.jaci.2014.05.013.

Spínola V, Eulogio J. Llorent-Martínez EJ, Castilho PC. 2014. Determination of vitamin C in foods: current state of method validation. J Chromatogr A 1369: 2-17. DOI: 10.1016/j.chroma. 2014.09.087.

Subedi PP, Walsh KB. 2011. Assessment of sugar and starch in intact banana and mango fruit by SWNIR spectroscopy. Postharvest Biol Tec 62: 238-245. DOI: 10.1016/j.postharvbio.2011.06. 014. 
Tiessen A. 2018. The fluorescent blue glow of banana fruits is not due to symplasmic plastidial catabolism but arises from insoluble phenols estherified to the cell wall. Plant Science: 275 , 75-83. DOI: 10.1016/j.plantsci.2018.07.006.

Wang H, Peng J, Xie C, Bao Y, He Y. 2015. Fruit quality evaluation using spectroscopy technology-a review. Sensor (Switzerland) 15: 1188911927. DOI: 10.3390/s150511889.
Zerbini PE, Vanoli M, Rizzolo A, Grassi M, de Azevedo Pimentel RM, Spinelli L, Torricelli A. 2015. Optical properties, ethylene production and softening in mango fruit. Postharvest Biol Tec 101: 58-65. DOI: 10.1016/j.postharvbio. 2014.11.008.

Zhu Q, He C, Lu R, Mendoza F, Cen H. 2015. Ripeness evaluation of 'sun bright' tomato using optical absorption and scattering properties. Postharvest Biol Tec 103: 27-34. DOI: 10. 1016/j.postharvbio.2015.02.007. 